\title{
ĐĂC ĐIỂM DICCH TỄ HỌC VÀ TÌNH HÌNH SƠ CỨU BAN ĐẦU Ở BỆNH NHI BỊ RẮN CHÀM QUẠP CẮN TẠI BỆNH VIỆN NHI ĐỒNG 1
}

\section{TÓM TẮT}

Mục tiêu: Xác định đặc điểm dịch tễ học và các biện pháp sơ cứu đúng, chưa đúng của thân nhân bệnh nhi đối các trẻ bị rắn chàm quạp cắn. Phương pháp nghiên cứu: Nghiên cứu hàng loạt ca trên 54 trẻ bi rắn chàm quạp cắn nhập khoa Cẩp cứu, bênh viện Nhi đồng 1 từ ngày 01/01/2011 đến ngày $31 / 12 / 2020$. Kết quả: Tuổi trung bình là 8,5 tuổi (2 tuổi - 15 tuổi), từ 6 tuổi trở lên chiếm $68,5 \%$. Tỉ lệ nam/nữ là $1,8 / 1$. Tai nan xảy ra quanh năm nhất là vào những tháng mùa mưa $66,8 \%$ từ tháng 5 đến tháng $11,77,8 \%$ bị cắn trong khoảng thời gian từ 12 giờ đến 24 giờ. Bình Phước là địa phương có bệnh nhi bi rắn chàm quap cắn nhập viên nhiều nhất $(29,6 \%)$. $53,7 \%$ trẻ bị cắn ở xung quanh nhà và trong nhà, đa số do vô tình cắn $96,3 \%, 57,4 \%$ trường hợp đem theo rắn sau khi bị rắn cắn. Hơn $70 \%$ vết cắn nằm ở chân, nhất là bàn chân $61,1 \%$. 72,2\% trường hợp sơ cứu không đúng (thường gặp là garrot, rạch da, hút nặn nọc độc, đắp thuốc...). 77,7\% trường hợp nhâp viển trong 24 giờ sau khi bị rắn cắn. Kết luận: Những bênh nhi có đi thây lang đắp thuốc thì có tỉ lệ nhiễm độc mức độ nặng cao gấp 3,2 lần (KTC 95\%: 1,4 $7,5)$, sự khác biệt có ý nghĩa thống kê, $p=0,002$. Thời gian nhập viện càng trễ thì tỉ lệ nhiễm độc mức độ nặng càng cao, có ý nghĩa thống kê với $p<0,001$.

Tư khóa: rắn cắn, rắn chàm quạp, sơ cứu

\section{SUMMARY}

EPIDEMIOLOGICAL CHARACTERISTICS

AND STUDY OF FIRST AID FOR CHILDREN WITH MALAYAN PIT VIPER BITES

HOSPITALIZED IN CHILDREN HOSPITAL 1

Objectives: To describe the epidemiological characteristics and study of first aid children with malayan pit viper bites. Methods: Descriptive study was conducted on 54 medical records of children with snake bites hospitalized in Children Hospital 1 from $01 / 01 / 2011$ to $31 / 12 / 2020$. Results: the average age is 8.5 years old ( 2 years old - 15 years old), 6 years old and above accounted for $68.5 \%$. The proportion of male and female is $1.8 / 1$. Accidents occur year-round especially during the rainy months of $66.8 \%$ from May to November, $77.8 \%$ are bitten between 12 hours and 24 hours. Binh Phuoc is the province which has the most Malayan pit viper bites hospitalized (29.6\%). $53.7 \%$ of the children were biten around and inside

*Bệnh viện Đa khoa Trung tâm Tiền Giang Chịu trách nhiệm chính: Nguyễn Thành Nam Email: thanhnam@pediatrician.vn Ngày nhận bài: 9.3.2021

Ngày phản biện khoa học: 7.5.2021

Ngày duyệt bài: 14.5.2021

\author{
Nguyễn Thành Nam*, Tạ Văn Trầm*
}

houses. The majority accidentally bit $96.3 \%, 57.4 \%$ of the cases brought the viper. More than $70 \%$ of the bites were in the legs, especially $61.1 \%$ of the feet. $72.2 \%$ of first aid cases were incorrect (common are used garrot, skin incision, venom attracting, drug laying ...). $77.7 \%$ of hospitalizations in 24 hours after bite. Conclusions: Patients who have a charlatan have a 3.2 times higher incidence of severe intoxication (KTC 95\%: 1.4-7.5), statistically significant difference, $\mathrm{p}=0.002$. The later the hospitalization time, the higher the incidence of severe intoxication, which is statistically significant with a $\mathrm{p}<0.001$.

Keywords; snake bites, Malayan pit viper, first aid.

\section{I. ĐẶT VẤN ĐỀ}

Hiện nay, có hơn 3800 loài rắn trên thế giới, 800 loài có độc chiếm 20\%, trong đó có khoảng 250 loài là thực sư nguy hiểm, có tầm quan trọng về mă̆t y tế(5). Theo thống kê của Tổ chức Y tế Thế giới, có hơn 5,5 triêu nạn nhân bị rắn cắn mỗi năm, trong đó 2,7 triệu người bị cắn bởi rắn độc, làm 81.000 đến 138.000 người chết và hơn 100.000 người để lại di chứng nặng nề. Việt Nam có khoảng 300.000 bênh nhân bị rắn trong một năm, số trường hợp tử vong dựa trên thống kê tại các bệnh viện lớn là không chính xác, vì phần lớn người bị rắn cắn chết ở các vùng nông thôn, nơi mà việc điều trị theo phương pháp cồ truyền thường dẫn đến cái chết cho bệnh nhân tai nhà (1).

Rắn chàm quạp hay còn gọi là rắn lục Mã Lai, rắn lục nưa...thuộc họ rắn lục Viperidae, rắn sống ở rừng thưa, gặp nhiều ở đồn điền cao su, hoạt động chủ yếu vào ban đêm. Nọc độc rắn chàm quạp chủ yếu gây rối loạn đông máu, tán huyết, hoai tử tổ chức ${ }^{(1)} \ldots$ Ngoài ra, vết thương do rắn cẳn có thể bị nhiễm khuẩn nặng do nhiễm trùng. Triệu chứng tại chỗ thường xuất hiện sớm sau khi bị rắn, nọc độc của rắn có thể gây tử vong hoặc gây tàn phế nếu không được sơ cứu và xử trí đúng, kịp thời. Trên thực tế, những sai lầm trong sơ cứu cũng như xử trí chưa đúng đã góp phần làm diễn tiến bênh nặng và tiên lượng xấu hơn đối với các trẻ bị rắn chàm quạp cắn nhập viện tại Bệnh viện Nhi đồng 1. Đó là lý do để chúng tồi làm nghiên cứu này với mục tiêu xác định tỉ lệ các đặc điểm dịch tể học của bênh nhân bị rắn chàm quạp cắn và xác định tî lệ các biện pháp sơ cứu đúng và chưa đúng của thân nhân bệnh nhi đối các trẻ bị rắn chàm quạp cắn. 


\section{II. ĐỐI TƯỢNG VÀ PHƯƠNG PHÁP NGHIÊN CỨU \\ 2.1 Đối tượng nghiên cứu}

Dân số chọn mấu. Tất cả bệnh nhi < 16 tuổi được chẩn đoán rắn chàm quạp cắn nhập khoa Cấp cứu Bệnh viện Nhi đồng 1 từ ngày 01/01/2011 đến ngày 31/12/2020.

Tiêu chuẩn lựa chọn. Người nhà đập chết rắn, mang rắn đến bệnh viện và được bác sĩ tại khoa Cấp cứu xác định là rắn chàm quạp, hoặc bênh nhi hoăcc người nhà nhìn thây rắn mô tả lai và xác định được rắn qua hình mẫu tại khoa Cấp cứu, hoặc dựa vào các triệu chứng lâm sàng, cận lâm sàng và địa điểm xảy ra tai nạn phù hợp với dich tễ rắn chàm quap cắn.

Tiêu chuẩn loại trừ. Không có đầy đủ dũ kiện theo bệnh án mấu, rắn cắn không phải rắn chàm quạp.

\subsection{Phương pháp nghiên cứu}

Thiết kế nghiên cứu:Mô tả loạt ca

Cỡ mẫu:Lây toàn bộ

Thu thập số liệu: Các thông tin được ghi vào phiếu điều tra. Sử dụng bảng câu hỏi và hồ sơ bệnh án.

Các bước tiến hành. Chọn danh sách tất cả các bệnh nhi bị rắn cắn nhập nhập khoa Cấp cứu Bệnh viện Nhi đồng 1 từ ngày 01/01/2011 đến ngày $31 / 12 / 2020$. Mượn hồ sơ bệnh án tại phòng lưu trữ hồ sơ, trên cơ sở tất cả bệnh nhi bị rắn cắn chỉ chọn ra hồ sơ bệnh nhi bị rắn chàm quạp cắn theo đúng tiêu chí lựa chơn rồi thu thập số liệu: ghi nhận đặc điểm dịch tể học, đánh giá các biện pháp sơ cứu đúng và chưa đúng của thân nhân bệnh nhi đối các trẻ bị rắn chàm quạp cắn.

Bảng 1. Phân độ nhiễm độc rắn chàm quạp cắn theo Bộ Y tế(1)

\begin{tabular}{|c|c|c|c|}
\hline Dấu hiệu & Nhe & Trung bình & Nặng \\
\hline $\begin{array}{l}\text { Dấu hieê̂u } \\
\text { tại chô̂ }\end{array}$ & $\begin{array}{c}\text { Có dấu răng, đauu nhẹ, sưng } \\
\text { không quá } 01 \text { khớp, vòng ch } \\
\text { nơi lớn nhất không quá } 2 \mathrm{~cm} \\
\text { và không hoại tử. }\end{array}$ & $\begin{array}{c}\text { Có dấu răng, đau, sưng tới } \\
\text { ikhớp thứ } 2 \text {, vòng chi nơi lớn } \\
\text { nhất } 2-4 c m \text { và hoại tử } \\
\text { nhỏ. }\end{array}$ & Có dấu răng, đau, sưng rộng. \\
\hline $\begin{array}{l}\text { Dấu hiệu } \\
\text { toàn thânn }\end{array}$ & Không & $\begin{array}{l}\text { Có (lừ đừ, dấu hiệu nhiễm } \\
\text { độc) } \\
\text { Không nguy hiểm }\end{array}$ & $\begin{array}{c}\text { Dấu hiệu quá } 2 \text { khớp hoặc sưng } \\
\text { nề lan đến thân minh, vờng chi } \\
\text { nơi lớn nhất > } 4 \mathrm{~cm} \text { và hoại tử } \\
\text { lan nguy hiểm cấp cứu (sốc, suy } \\
\text { hô hấp, rối loạn tri giác...) }\end{array}$ \\
\hline $\begin{array}{l}\text { Rối loạn } \\
\text { đông máu }\end{array}$ & Không & $\begin{array}{l}\text { Rối loạn đông máu nhe } \\
\text { Không dấu hiệu xuất huyết } \\
\text { toàn thân }\end{array}$ & $\begin{array}{c}\text { Rối loạn đông máu năng } \\
\text { Xuất huyết toàn thân (ói máu, } \\
\text { tiểu máu, xuất huyết não) }\end{array}$ \\
\hline
\end{tabular}

Xử trí số liệu: Các số liệu sẽ được mã hóa, nhập liệu và phân tích theo phương pháp thống kê y học, lập bảng vẽ biểu đồ, sử dụng các phần mềm EpiData Manager; Stata 16; Microsoft office 365. Sử dụng thống kê mô tả và thống kê phân tích.

Y đức: Nghiên cứu đã được hội đồng $Y$ đức Bệnh viện Nhi Đồng 1 thông qua, số 534/GCNBVND1.

\section{KẾT QUẢ NGHIÊN CỨU}

Trong thời gian 10 năm từ ngày $01 / 01 / 2011$ đến ngày $31 / 12 / 2020$ có 54 trẻ bị rắn chàm quạp cắn đủ tiêu chuẩn đưa vào nghiên cứu của chúng tôi, ghi nhận kết quả như sau:

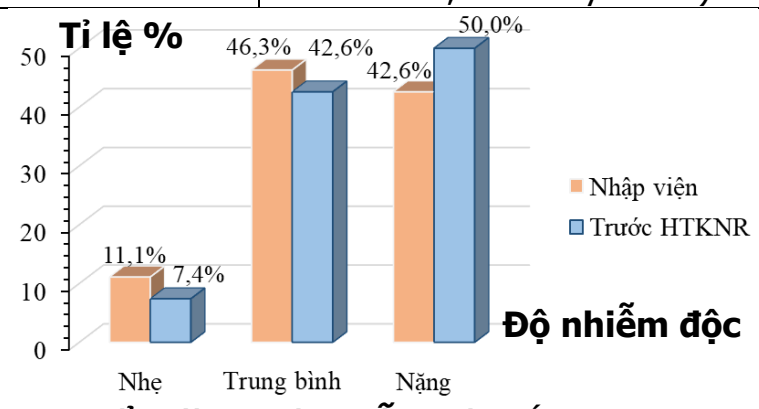

Biểu đồ 1. Độ nhiễm độc rắn $(N=54)$

Nhận xét: Tại thời điểm nhập viện, độ nhiễm độc trung bình và độ nhiễm độc nặng lần lượt chiếm $46,3 \%$ và $42,6 \%$. Tại thời điểm trước khi truyền huyết thanh kháng nọc rắn, độ nhiễm độc trung bình và độ nhiễm độc nặng lần lượt chiếm $42,6 \%$ và $50,0 \%$.

Bảng 2. Đặc điểm dịch tễ học và mức độ nhiếm độc ( $N=54)$

\begin{tabular}{|c|c|c|c|c|}
\hline \multirow{2}{*}{ Đặc điểm } & \multirow{2}{*}{ N (\%) } & \multicolumn{2}{|c|}{ Độ nhiềm độc } & \multirow[b]{2}{*}{$\mathbf{p}$} \\
\hline & & Nhẹ, TB N (\%) & Nặng N (\%) & \\
\hline Giới: & $35(64,8)$ & $18(51,4)$ & $17(48,6)$ & $078^{a}$ \\
\hline Nũ̃ & $19(35,2)$ & $9(47,4)$ & $10(52,6)$ & \\
\hline
\end{tabular}




\begin{tabular}{|c|c|c|c|c|}
\hline Nhóm tuổi: $<6$ tuối & $17(31,5)$ & $8(47,1)$ & $9(52,9)$ & \multirow{3}{*}{$0,67^{a}$} \\
\hline $6-10$ tuối & $17(31,5)$ & $10(58,8)$ & $7(41,2)$ & \\
\hline $11-15$ tuối & $20(37,0)$ & $9(45,0)$ & $11(55,0)$ & \\
\hline Địa điểm bị rắn cắn: Trong nhà & $10(18,5)$ & $5(50,0)$ & $5(50,0)$ & \multirow{6}{*}{$0,63^{\beta}$} \\
\hline Xung quanh nhà & $19(35,2)$ & $10(52,6)$ & $9(47,4)$ & \\
\hline Trên đường đi & $18(33,3)$ & $8(44,4)$ & $10(55,6)$ & \\
\hline Đồng ruộng, rây & $4(7,4)$ & $3(75,0)$ & $1(25,0)$ & \\
\hline Rừng núi & $2(3,7)$ & 0 & $2(100,0)$ & \\
\hline Khác (resort) & $1(1,9)$ & $1(100,0)$ & 0 & \\
\hline \multicolumn{5}{|l|}{ Đặc điếm nhận diện rắn } \\
\hline Đem theo rắn & $31(57,4)$ & $17(54,8)$ & $14(45,2)$ & \multirow{7}{*}{$0,41^{a}$} \\
\hline Không đem theo rắn & $23(42,6)$ & $10(43,5)$ & $13(46,5)$ & \\
\hline Vị trí vết căn: Bàn chân & $33(61,1)$ & $17(51,5)$ & $16(48,5)$ & \\
\hline Bàn tay & $14(25,9)$ & $7(50,0)$ & $7(50,0)$ & \\
\hline Cắng chân & $5(9,3)$ & $2(40,0)$ & $3(60,0)$ & \\
\hline Cằng tay & $1(1,9)$ & $1(100,0)$ & 0 & \\
\hline Đùi & $1(1,9)$ & 0 & $1(100.0)$ & \\
\hline
\end{tabular}

${ }^{a}$ Chi $^{2}$ test, ${ }^{\beta}$ Fisher's exact test

Nhận xét: Tỉ lệ nam/nữ = 1,8/1. Tuổi trung bình $8,5 \pm 4,2,68,5 \%$ từ 6 tuổi trở lên. Đa số các trẻ bị rắn cắn đều do vô tình $(96,3 \%)$. $53,7 \%$ trẻ bị cắn ở sân, vườn cây xung quanh nhà và trong nhà. Có $31 / 54(57,4 \%)$ đem theo rắn chàm quạp, 23/54 (42,6\%) xác định rắn qua việc nhìn thây, mô tả lại, nhận diện qua ảnh mẫu cũng như kết hợp các đặc điểm dịch tễ học, triệu chứng lâm sàng và cận lâm sàng. Đa số $(70,4 \%)$ vết cẳn nằm ở chân, trong đó vị trí cắn ở bàn chân chiếm nhiều nhất $(61,1 \%)$.

Bảng 3. Phân bố theo địa phướng $(\mathrm{N}=54)$

\begin{tabular}{|c|c|c|}
\hline Địa phương & $\mathbf{N}$ & Tỉ lệ (\%) \\
\hline Bình Phước & 16 & 29,6 \\
\hline Bà Rịa Vũng Tàu & 9 & 16,7 \\
\hline
\end{tabular}

\begin{tabular}{|c|c|c|}
\hline Bình Thuận & 8 & 14,8 \\
\hline Bình Dương & 7 & 13,0 \\
\hline An Giang & 3 & 5,6 \\
\hline Đắc Nông & 3 & 5,6 \\
\hline Ninh Thuận & 2 & 3,7 \\
\hline Gia Lai & 1 & 1,9 \\
\hline Lâm Đồng & 1 & 1,9 \\
\hline Quảng Nam & 1 & 1,9 \\
\hline Đồng Nai & 1 & 1,9 \\
\hline Campuchia & 2 & 3,7 \\
\hline
\end{tabular}

Nhân xét: $2 / 54$ (3,7\%) trẻ bi rắn chàm quap cắn nhập Bệnh viện Nhi đồng 1 đển từ Campuchia. Bình Phước là địa phương có số trẻ bị rắn nhâp viện nhiều nhất 16/54 (29,6\%), kế đến là Bà Rịa Vũng Tàu, Bình Thuận, Bình Dương....

\section{Bảng 4. Thời gian rắn cắn và mức độ nhiễm độc $(\mathrm{N}=54)$}

\begin{tabular}{|c|c|c|c|c|c|}
\hline \multirow{2}{*}{ Đặc điểm } & \multirow{2}{*}{ N (\%) } & \multicolumn{2}{|c|}{ Độ nhiếm độc } & \multirow{2}{*}{$\begin{array}{c}\text { PR } \\
\text { (KTC 95\%) }\end{array}$} & \multirow{2}{*}{$\mathbf{p}$} \\
\hline & & Nhe, TB N & Năng N & & \\
\hline \multicolumn{6}{|c|}{ Thời điểm bị rằn trong ngày } \\
\hline 0 giờ - 6 giờ & $3(5,6)$ & 2 & 1 & 1 & \multirow{4}{*}{0,47} \\
\hline$>6$ giờ - 12 giờ & $9(16,7)$ & 3 & 6 & $1,3(0,8-2,0)$ & \\
\hline$>12$ giờ - 18 giờ & $19(35,2)$ & 8 & 11 & $1,2(0,8-1,8)$ & \\
\hline$>18$ giờ -24 giờ & $23(42,6)$ & 14 & 9 & $1,0(0,7-1,6)$ & \\
\hline \multicolumn{6}{|c|}{ Thời điếm bị răn cắn trong năm } \\
\hline Tháng $1-3$ & $11(20,4)$ & 6 & 5 & 1 & \multirow{4}{*}{0,79} \\
\hline Tháng 4-6 & $26(48,1)$ & 14 & 12 & $1,0(0,8-1,3)$ & \\
\hline Tháng 7 - 9 & $9(16,7)$ & 3 & 6 & $1,1(0,9-1,5)$ & \\
\hline Tháng $10-12$ & $8(14,8)$ & 4 & 4 & $1,0(0,8-1,4)$ & \\
\hline \multicolumn{6}{|c|}{ Thời gian rắn cắn đến khi nhập viện } \\
\hline$\leq 6$ giờ & $24(44,4)$ & 16 & 8 & 1 & \multirow{4}{*}{$<0,001^{\beta}$} \\
\hline$>6$ giờ - 12 giờ & $12(22,2)$ & 8 & 4 & $1,4(1,2-1,8)$ & \\
\hline$>12$ giờ - 24 giờ & $6(11,1)$ & 2 & 4 & $2,0(1,4-3,2)$ & \\
\hline$>24$ giờ & $12(22,2)$ & 1 & 11 & $2,7(1,7-5,8)$ & \\
\hline
\end{tabular}


quanh năm, 66,8\% trường hợp bị cắn xảy ra vào các tháng mùa mưa từ tháng 5 đến tháng 11 , có khí hậu nóng ẩm thích hợp cho rắn hoạt động và sinh sản. 44,4\% trường hợp nhập viện trong 6 giờ đầu tiên sau khi bị rắn cắn. $77,7 \%$ các trường hợp nhập viện trong 24 giờ sau khi bị rắn cắn. Thời gian nhập viện càng trễ thì tỉ lệ nhiễm độc mức độ nặng càng cao, có ý nghĩa thống kê với $\mathrm{p}<0,001$.
Bảng 5. Điều trị trước khi đến bệnh viện $(N=54)$

\begin{tabular}{|c|c|c|}
\hline & $\mathbf{N}$ & Tỉ lệ (\%) \\
\hline $\begin{array}{c}\text { Xử trí trước khi đến BV } \\
\text { Nhi đồng 1 }\end{array}$ & $\mathbf{4 3}$ & $\mathbf{7 9 , 6}$ \\
\hline Xử trí tại nhà & 28 & 51,9 \\
\hline Thầy lang & 9 & 16,7 \\
\hline Bệnh viện tuyện trước & 36 & 66,7 \\
\hline $\begin{array}{c}\text { Đến thắng Bệnh viện } \\
\text { Nhi đồng 1 }\end{array}$ & $\mathbf{1 1}$ & $\mathbf{2 0 , 4}$ \\
\hline
\end{tabular}

Bảng 6. Biện pháp sơ cứu và mức độ nhiễm độc $(\mathrm{N}=54)$

\begin{tabular}{|c|c|c|c|c|c|}
\hline \multirow{2}{*}{ 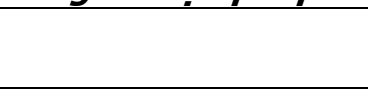 } & \multirow{2}{*}{ N (\%) } & \multicolumn{2}{|c|}{ Độ nhiềm độc } & \multirow{2}{*}{$\begin{array}{c}\text { PR } \\
\text { (KTC 95\%) }\end{array}$} & \multirow[b]{2}{*}{$\mathbf{p}$} \\
\hline & & Nhẹ, TB N & Nặng N & & \\
\hline Sơ cứu đúng & $4(7,4)$ & 3 & 1 & & \\
\hline Rửa vết thương & $7(13,0)$ & 4 & 3 & $0,8(0,2-3,0)$ & 0,68 \\
\hline Bất động bằng nẹp & $1(1,9)$ & 0 & 1 & & \\
\hline Sơ cứu không đúng & $39(72,2)$ & 16 & 23 & & \\
\hline Garrot & $18(33,3)$ & 8 & 10 & $1,3(0,6-2,7)$ & 0,56 \\
\hline Rạch da & $8(14,8)$ & 3 & 5 & $1,7(0,4-6,3)$ & 0,44 \\
\hline Hút, nặn nọc độc & $11(20,4)$ & 4 & 7 & $1,8(0,6-5,3)$ & 0,31 \\
\hline Đắp lá, thuốc & $21(38,9)$ & 5 & 16 & $3,2(1,4-7,5)$ & $0,002^{a}$ \\
\hline Uống thuốc nam & $8(14,8)$ & 2 & 6 & $3,0(0,7-13,6)$ & 0,12 \\
\hline Khống sơ cứu & $11(20,4)$ & 8 & 3 & & \\
\hline
\end{tabular}

${ }^{a} \mathrm{Chi}^{2}$ test

Nhân xét: $79,6 \%$ các trường hợp có xử trí trước khi đến bệnh viện, xử trí tại nhà $51,9 \%$, đến thầy lang $16,7 \%$ và $66,7 \%$ bệnh nhi đến bệnh viện tuyến trước trước khi chuyển đến Bệnh viện Nhi đồng 1. 72,2\% trường hợp sơ cứu không đúng, các biện pháp sơ cứu không đúng thường gặp là đắp lá, thuốc nam, garrot... Ớ những bệnh nhi có đi thầy lang đắp lá, thuốc thì có tỉ lệ nhiễm độc mức độ nặng cao gấp 3,2 lần (KTC 95\%: 1,4 - 7,5), sự khác biệt có ý nghĩa thống kê, $p=0,002$.

\section{BÀN LUÂN}

Trong nghiên cứu của chúng tôi, có $64,8 \%$ là trẻ nam, 35,2\% là trẻ nữ. Tî lệ trẻ nam/ nữ là $1,8 / 1$. Kết quả này cũng tương tự kết quả của các tác giả khác, cho thấy nam bị rắn cắn nhiều hơn nữ. Nghiên cứu của Lê Thị Thùy Linh trên 87 trường hợp rắn độc cắn tại Bệnh viện Nhi đồng 2 trong 5 năm từ 2010 đến năm 2014, tỉ lệ nam/ nữ là $1,7 / 1^{(2)}$. Điều này có thể lý giải là nam vốn hiếu động hơn nữ, thích mạo hiểm hơn nên có nguy cớ bị rắn cắn cao hơn. Tuổi trung bình là 8,5 tuổi, tuổi nhỏ nhất là 2 tuổi và lớn nhất là 15 tuổi, 68,5 \% trẻ bị cắn từ 6 tuổi trở lên, trên 10 tuổi 37,0\%. Kết quả tương tự nghiên cứu của Ngô Ngọc Quang Minh trên 69 trường hợp rắn độc cắn tại Bệnh viện Nhi đồng 1 từ năm 2002 đến năm 2003, tuổi trung bình là 9,22 tuổi, nhỏ nhất 2 tuổi, lớn nhất 15 tuổi, từ 6 tuổi trở lên cũng chiếm tỉ lệ ưu thế $85,5 \%$, trên 10 tuổi $37,7 \% \%^{(3)}$. Giống như các tai nạn khác, những trẻ nam thường hiếu động và những trẻ trong độ tuổi đi học trở lên thường cha me ít quan tâm để mắt hơon trẻ nhỏ, để chạy chới tự do các em có điều kiện ra khỏi nhà hoặc có nhiều hoạt động sinh hoạt tự ý hơn nên dễ vô tình bị rắn cắn hơn.

$53,7 \%$ trẻ bị cắn ở sân, vườn cây xung quanh nhà và trong nhà, trong đó tai nạn xảy ra ở sân, vườn cây xung quanh nhà chiếm tỉ lệ cao nhất $35,2 \%$. Theo tác giả Mã Tú Thanh, 70,2\% trẻ bị cắn tại nhà và xung quanh nhà, trong đó tai nạn xảy ra ở sân, vườn xung quanh nhà chiếm tỉ lệ cao nhất (gần $1 \frac{1}{2}$ trường hợp) ${ }^{(4)}$. Có sự khác biệt so tai nạn của người lớn chủ yếu do nạn nhân chủ động bắt rắn, với nghiên cứu của Nualnong Wongtongkam về 225 bệnh nhi bị rắn chàm quạp cắn tại Thái Lan gồm 145 bệnh nhi tiến cứu từ tháng 4 năm 2002 đến tháng 6 năm 2003 và 80 bệnh nhi hồi cứu từ năm 2001, hầu hết vết cắn xảy ra ngoài đường tương tự như tác giả Kanthika Kraisawat nghiên cứu trển 153 bệnh nhi bị rắn chàm quạp cắn từ tháng 01 năm 2006 đến tháng 11 năm 2017 tại Bệnh viện Songklanag me, Thái Lan, 46,4\% tai nạn xảy ra ngoài đường ${ }^{(6,7)}$.

Trong 54 trẻ bị rắn chàm quạp cắn nhập viện Bệnh viện Nhi đồng 1 , ghi nhận Bình Phước là địa phương có số trẻ bị rắn cắn nhiều nhất 
$(29,6 \%)$, kễ đến là Bà Rịa Vũng Tàu $(16,7 \%)$, Bình Thuận (14,8\%), Bình Dương $(13,0 \%) \ldots$ đây đều là những nơi có nhiều đồng ruộng, đồn điền cao su, bui cỏ và điều kiện ẩm thuận lợi cho rắn sinh sôi, phát triển. 54 BN trong nghiên cứu của chúng tôi, vết cắn ở chân chiếm đa số $70,4 \%$, trong đó bàn chân chiếm $61,1 \%$. Có 1 trường hợp bị cắn ở đùi phải $(1,9 \%)$, không ca nào bị cẳn ở thân người hay vùng đầu mặt cổ. Kết quả này tương tự với nghiên cứu của Mã Tú Thanh, vết cắn ở chân chiếm $70,7 \%$ trong đó bàn chân chiếm $61,2 \%{ }^{(4)}$. Một số tác giả nước ngoài cũng đưa ra kết quả tương tự, Nualnong Wongtongkam: vết cắn ở chân là $69,7 \%$ ở nhóm tiến cứu, $80 \%$ ở nhóm hồi cứu $(7)$. Vị trí vết cắn tùy thuộc vào nơi sinh sống của từng loại rắn, tùy vào hoàn cảnh bị cắn. Do rắn chàm quạp thích sống ở khu đất rừng thấp, đồn điền cao su, bênh nhi trong nghiên cứu này là trẻ em đa số do vô tình dẫm phải nên thường vết cắn ở chi dưới nhiều hơn, nhất là ở bàn chân.

$77,8 \%$ bệnh nhi bị rắn cắn trong khoảng từ đầu giờ chiểu đến tối (từ 12 giờ đến 24 giờ), trong đó bị cắn nhiều nhất là khoảng thời gian sau 18 giờ đến 24 giờ (gần $1 / 2$ trường hợp). Ghi nhận này tương tự nghiên cứu của Ngô Ngọc Quang Minh, khoảng từ 16 giờ đến 24 giờ chiếm nhiều nhất $(52,2 \%)^{(3)}$, theo tác giả Mã Tú Thanh, 66,7\% trường hợp bệnh nhi bị cắn từ 12 giờ đến 24 giờ(4). tương tự như kết quả nghiên cứu của tác giả Nualnong Wongtongkam cho thấy rắn cắn xảy ra suốt cả ngày, chủ yếu là từ 8 giờ sáng đến 16 giờ tương ứng với thời gian làm việc trên đồng ruộng hoăcc đồn điên cao su(7). Bểnh nhi có thể bị rắn cẳn quanh năm, nhưng chủ yếu vào những tháng mùa mưa từ tháng 5 đến tháng 11 , chiếm tỉ lệ $66,8 \%$, đây là những tháng có khí hậu nóng ẩm phù hợp cho các loài rắn sinh sôi, phát triển và hoạt động. Kết quả của chúng tôi phù hợp với kết quả của Mã Tú Thanh và Ngô Ngọc Quang Minh với tỉ lệ lần lượt là $76,1 \%$ và $74 \%$ bệnh nhi bị rắn cắn từ tháng 5 đến tháng $11^{(3,4)}$. Theo nghiên cứu của Nualnong Wongtongkam ghi nhận mùa rắn cắn là vào tháng 5 đâu mùa gió mùa $(19,31 \%)^{(7)}$. Tác giả Kanthika Kraisawat cũng ghi nhân bệnh nhi có thể bị rắn cắn quanh năm chủ yếu vào mùa hè, từ tháng 4 đến tháng 11 chiếm tỉ lệ $70,6 \%{ }^{(6)}$. Qua nghiên cứu chúng tôi thấy, thời gian từ lúc bi rắn cắn đến khi nhập viên có trung vị là 7 giờ, sớm nhất là 1,5 giờ và trễ nhất là gân 7 ngày. $44,4 \%$ các trường hợp nhập viện trong 6 giờ và $77,7 \%$ nhập viện trong 24 giờ đầu sau khi bị rắn cắn. Kết quả này tương tự nghiên cứu của $\mathrm{Ngô}$
Ngọc Quang Minh, 40\% nhập viện trước 6 giờ và $80 \%$ nhập viện trước 24 giờ(3). Tác giả Lê Thị Thùy Linh cũng ghi nhận $48,3 \%$ trẻ bị cắn đên sớm trước 6 giờ, $82,7 \%$ nhập viên trước 24 giờ(2). Theo nghiên cứu của Mã Tú Thanh trên 148 trẻ bị rắn lục tre cắn cho thấy thời gian trung bình từ lúc rắn cắn đến khi nhập viện là $7,7 \pm 12,1$ giờ, $74,1 \%$ nhập viện trước 6 giờ và $93,2 \%$ nhập viện trong 24 giờ đầu ${ }^{(4)}$. Theo các tác giả nước ngoài nghiên cứu trên người lớn bị rắn chàm quạp cắn như tác giả Nualnong Wongtongkam, Kanthika Kraisawat ghi nhận thời gian trung bình từ lúc bị rắn cắn đến khi nhâpp viện lần lượt là 175 phút trong nhóm nghiên cứu tiến tới và 40 phút ${ }^{(6,7)}$. Những triệu chứng do rắn chàm quạp cắn thường xuất hiện sớm, đó là nguyên nhân đưa bệnh nhi đến bệnh viện sớm trong ngày đầu tiên, nhất là trong 6 giờ đầu tiên khi mà các triêuu chứng tai chỗ cũng như toàn thân ngày càng tăng. Thời gian nhập viện sau khi bị rắn cắn tùy thuộc vào sự hiểu biết của phụ huynh, nơi cư ngư và điêu trị sai lầm trước đó càng làm châmm trế thời gian đưa đến bênh viên.

Chúng tôi ghi nhận gần 80\% các trường hợp có xử trí trước khi đến Bệnh viện Nhi đồng 1 , trong đó $66,7 \%$ trường hợp đến cơ sở y tế trước khi chuyển đến Bệnh viện Nhi đồng 1 , tất cả các ca này đều được xử trí sơ cứu đúng làm chậm quá trình hấp thu nọc rắn như rửa vết thương, bất động bằng nẹp trước khi chuyển viện. Tuy nhiên trước khi chuyển đến cơ sở y tế hay bệnh viện gần 3/4 các trường hợp đều nhận các biện pháp sơ cứu không đúng tại nhà hoặc đi thầy lang đắp lá, uống thuốc nam làm chậm trễ việc điều trị đặc hiêu huyết thanh kháng nọc rắn như garrot $(33,3 \%)$, rạch da, nặn hút nọc độc $(35,2 \%)$, đắp lá, uống thuốc nam $(53,7 \%)$, và đây là những ca thường đến bênnh viện trễ, biểu hiện tại chỗ nhiều. Trong nghiền cứu của Mã Tú Thanh cũng ghi nhận gần 3/4 trường hợp sơ cứu không đúng như garrot $(56,0 \%)$, rạch da, nặn hút nọc độc $(29,7 \%)$, đắp lá, uống thuốc nam $(30,4 \%)^{(4)}$. Tác giả Lê Thị Thùy Linh ghi nhận có $75,9 \%$ có xử trí trước khi đến bệnh viện, các biện pháp sơ cứu không đúng chiểm 37,9\% (2). Trong nghiên cứu của Nualnong Wongtongkam trên 225 bệnh nhi bị rắn chàm cắn tại Thái Lan, trong nhóm 145 bệnh nhi tiến cứu có 39,3\% garrot trước khi vào viênn ${ }^{(7)}$. Như vầy, tỉ lê sơ cứu không đúng trước khi vào viên vẫn còn chiếm tỉ lệ khá cao, làm chậm trễ thời gian đến bệnh viện, tăng nguy cơ nhiễm độc mức độ nặng. Theo bảng 6 cho thấy, ở những bênh nhi có đi thầy lang, đắp thuốc thì có tỉ lệ nhiễm độc mức 
độ nặng cao gấp 3,2 lần (KTC 95\%: 1,4 - 7,5), có ý nghĩa thống kê, $\mathrm{p}=0,002$.

\section{KẾT LUÂN}

Mức độ nhiễm độc nhẹ, trung bình và nặng lần lượt chiếm $50 \%$ và $50 \%$ trường hợp tại thời điểm trước truyền huyết thanh kháng nọc rắn. Đa số bệnh nhi bị rắn chàm quạp cắn từ 6 tuổi trở lên chiếm $68,5 \%$, tỉ lệ nam/nữ là 1,8/1.Tai nạn xảy ra quanh năm nhất là vào những tháng mùa mưa $66,8 \%$ từ tháng 5 đến tháng 11 , $77,8 \%$ bị cắn trong khoảng thời gian từ 12 giờ đến 24 giờ. Bình Phước là địa phương có bệnh nhi bị rắn chàm quạp cắn nhập viện nhiêu nhất $(29,6 \%) .53,7 \%$ trẻ bị cắn ở xung quanh nhà và trong nhà, đa số do vô tình cắn $96,3 \%$. Hơn $70 \%$ vết cắn nằm ở chân, nhất là bàn chân $61,1 \% .57,4 \%$ trường hợp đem theo rắn sau khi bị rắn cắn, $72,2 \%$ trường hợp sơ cứu không đúng (thường gặp là garrot, rạch da, hút nặn nọc độc, đắp thuốc...). $77,7 \%$ trường hợp nhập viện trong 24 giờ sau khi bị rắn cắn. Vì vậy cần tăng cường tuyên truyền giáo dục thân nhân bệnh nhi về phòng tránh rắn chàm quạp cắn; hướng dẫn thân nhân bệnh nhi biết cách xử trí khi trẻ bị rắn cắn để làm chậm hấp thu nọc rắn; không garrot, chích, rạch, hút nọc, đắp thuốc nam... vừa mất thời gian nhập viện vừa tăng nguy cơ nhiễm trùng, hoại tử.

\section{TÀI LIÊU THAM KHẢO}

1. Bộ Y tế (2017) Hướng dẫn chẩn đoán và xử trí ngộ độc, Nhà xuất bản Y hoc, Hà Nội, tr.89-124.

2. Lê Thị Thùy Linh (2016) "Tình hình sử dụng huyết thanh kháng noc rắn tai Bệnh viên Nhi Đồng 2 từ năm 2010 đến 2014". Tạp chí Y học TP. Hồ Chí Minh, 20 (4), tr.79-86.

3. Ngô Ngọc Quang Minh, Vũ Huy Trụ (2005) "69 trường hợp rắn độc cắn tại Bệnh viện Nhi Đồng 1". $Y$ hoc Thức Hành (503), 2 , tr.55-58.

4. Mã Tú Thanhh, Pham Vắn Quang (2017) "Đặc điểm dịch tế, lâm sàng, cận lầm săng ở bệnh nhi bi rắn lục tre cắn tai Bềnh viên Nhi Đông 1 ". Tap chí Y học TP. Hồ Chí Minh, 21 (4), tr.252-259.

5. J. P. Chippaux, A. Massougbodji, A. G. Habib (2019) "The WHO strategy for prevention and control of snakebite envenoming: a sub-Saharan Africa plan". J Venom Anim Toxins Incl Trop Dis, 25, e20190083.

6. Kanthika Kraisawat, Nattaya Promwang (2020) "Duration after Malayan Pit Viper Bite to Detect Coagulopathy in Songklanagarind Hospital". Journal of Health Science and Medical Research, 38, 93-101.

7. Nualnong Wongtongkam, Chitr Sitthi-amorn, Kavi Ratanabanangkoon (2005) "A Study of 225 Malayan Pit Viper Bites in Thailand". Military medicine, 170, pp.342-8.

\title{
THÁI Độ CỦA HỌC SINH VÊ BỮA ĂN BÁN TRÚ TẠI MộT SỐ TRƯỜNG TIỂU HỌC TRÊN ĐỊA BÀN HÀ NộI
}

\author{
Lê Văn Tuấn ${ }^{1}$, Hoàng Thị Thanh Thủy ${ }^{2}$, Hoàng Thị Hải Vân ${ }^{3}$, \\ Phạm Ngọc Toàn ${ }^{4}$ Hoàng Lê Lan ${ }^{5}$, Trần Thị Thu Trang
}

\section{TÓM TẮT}

Mục tiêu: Dịch vụ ăn bán trú tại trường tiểu hoc đóng vai trò quan trọng trong quá trình học tập, phát triển thể lực, tầm vóc và nâng cao sức khỏe của học sinh. Nghiển cứu nhằm đánh giá thái đô của học sinh về bữa ăn bán trú tại một số trường tiểu học trên đia bàn Hà Nội. Phương pháp:Tiến hành nghiền cứu mô

\footnotetext{
${ }^{1}$ Vụ Giáo dục Thể chât, Bộ Giáo dục và Đào tạo 2Bênh viện 09, Sở Y tế Hà Nôi.

${ }^{3}$ Trường Đại họ Y Hà Nội.

${ }^{4}$ Bệnh viện Nhi Trung ương.

${ }^{5}$ Trường Trung họ Phổ thông chuyên khoa họ tự nhiên, Đại học Khoa học Tự nhiên, Đại học Quốc gia Hà Nội.

Chịu trách nhiêm chính: Hoàng Thị Hải Vân

Email: hoangthihaivan@hmu.edu.vn

Ngày nhận bài: 10.3.2021

Ngày phản biện khoa học: 7.5.2021

Ngày duyệt bài: 13.5.2021
}

tả cắt ngang trên 996 học sinh từ tháng 10/2019 $5 / 2020$, tai 09 trường tiểu hoc của Thành phố Hà Nôii. Kết quả:Tỉ lệ học sinh thích/rất thích bữa ăn nội trú lần lượt là $30 \%$ và $38 \%$, có sự khác biệt giữa học sinh 3 khu vực $(p<0,05)$. "Đồ ăn đa dạng, có nhiều món ngon" và "hợp khẩu vị" là lí do chính các em thích bữa ăn nội trú. Với những học sinh không thích ăn tại trường, lý do "không hợp khẩu vị" chiếm tỉ lệ cao trong cả 3 nhóm học sinh, và cao nhất trong 2 nhóm học sinh Trung tâm và Ngoại thành. Đối với học sinh Nông thôn, "đồ ăn không ngon" và "thiếu thân thiện của các cô nhân viên nhà bếp" là những lý do đáng được chú ý. Kết luận: Để phát huy được giá trị của bữa ăn bán trú tại các trường tiểu học và kích thích sự hứng thú trong học sinh, khônng chỉ đa dạng thực đơn, đảm bảo vệ sinh an toàn và dinh dưỡng, việcđào tạo nhân viên nhà bếp của trường, xây dựng môi trường thân thiện cho các em, tạo môi trường ăn uống có mang tính sư phạm - giáo dục cao cũng cần được chú trọng. Nội

Tư khóa: học sinh tiểu học, bữa ăn bán trú, Hà 